WIELKIE TEMATY KULTURY W LITERATURACH SKOWIAŃSKICH

Slavica Wratislaviensia CLXVIII • Wrocław 2019•AUWr No 3875

DOI: $10.19195 / 0137-1150.168 .8$

Data przesłania artykułu: 6.09.2017

Data akceptacji artykułu: 15.01.2018

MARTA ZAMBRZYCKA

Uniwersytet Warszawski, Polska

\title{
Obraz śmierci masowej w nowelach Mykoły Chwylowego Бараки, щзо за містом і Я (Романтика)
}

Problematyka śmierci zadawanej na masową skalę i w imię różnie rozumianej „wyższej konieczności” weszła na stałe w kanon tematów dwudziestowiecznej literatury. Powszechnie znane są dzieła pisarzy rosyjskich, polskich i węgierskich; trochę mniej wiemy o obecności tej tematyki w obszarze ukraińskojęzycznym, a przecież Ukraina to państwo wyjątkowo boleśnie doświadczone przez historię. Wojny, rewolucje, polityczny terror, dziesięciolecia totalitaryzmu z jego systemem masowego uśmiercania i zniewolenia czy wreszcie apogeum koszmaru wielki głód '33 roku.

Jako egzemplifikację tematyki śmierci masowej wybrałam dwie nowele-etiudy Mykoły Chwylowego, którego przynależność do pokolenia zwanego Rozstrzelanym Odrodzeniem oraz śmierć samobójcza, będąca protestem wobec stalinizmu i wyrazem rozpaczy w obliczu nowej rzeczywistości, wpisują się już same w sobie w tematykę śmierci zadawanej na masową skalę i uwarunkowaną kontekstem politycznym. Uśmiercanie w imię „wyższej konieczności” jest też motywem pojawiającym się w niektórych utworach Chwylowego, zwłaszcza w noweli-etiudzie Я (Романтика) (1924) oraz w noweli Бараки, що за містом (1923).

Mykoła Chwylowyj to jeden z ważniejszych twórców tak zwanego Rozstrzelanego Odrodzenia. Jurij Lawrinenko w antologii dotyczącej tego pokolenia pisze, że Chwylowyj podczas swojego niedługiego życia: „устиг стати провідним новелістом, творцем власної літературної школи i власного стилю, організатором і головним ідейним речником українського відродження 
в УРСР"1. Albert Nowacki podkreśla zaś, iż autor ten jest jedną z najtragiczniejszych i najbardziej kontrowersyjnych postaci w historii ukraińskiej literatury ${ }^{2}$. Śmierć pisarza stanowiła preludium do jego ,śmierci publicznej”, ponieważ pamięć o Chwylowym, jego twórczości oraz dyskusji kulturalnej, którą wywołał, władza radziecka starała się wykreślić z pamięci ukraińskiego społeczeństwa. Jak pisze Jurij Szapowat:

Pamięć o Chwylowym próbowano wymazać na wieki [...]. Poza wyłączonymi dokumentami nie zachował się najmniejszy fragment kliszy z jego zdjęciami, istnieje również niewiele odbitek. Pochowano go w maju 33 r. Niebawem grób zrównano z ziemiąa ${ }^{3}$.

Hryhorij Hrabowycz zauważa, że milczenie wokół Chwylowego trwało długie dziesięciolecia, aż do czasu gorbaczowowskiej pierestrojki. Jeśli wspominano o nim w naukowych i popularnonaukowych pracach, to wyłącznie w negatywnym kontekście 4 .

Czasy, w których żył Chwylowyj, to okres bardzo burzliwy: I wojna światowa, rewolucja w Rosji oraz wojna domowa wprowadzająca anarchię i bezustanną zmianę władzy, a zakończona ostatecznie usankcjonowaniem rządów bolszewików. Okrucieństwo tych czasów znajduje wyraz w wybranych utworach autora. Krótka nowela Бараки, щио за містом ukazuje dehumanizację zarówno życia, jak i śmierci w tych ,nowych czasach”. Akcja utworu rozgrywa się w 1918 roku, podczas niemieckiej okupacji i powstania Hetmanatu Pawła Skoropadskiego. W tytułowych barakach za miastem dogorywają ofiary trwających zmagań wojennych, a dokładniej więźniowie-wojskowi. Bohaterami opowiadania są sanitariusze, których zadaniem jest ,praca z półtrupami”, właściwie polegająca jedynie na zbiorowej utylizacji ich ciał. Pierwszym, co uderza czytelnika, jest ogromna liczba chorych i umierających ludzkich ciał: „Ах Німеччино, Німеччино! Кожного дня заганяєм у ворота чотири-п'ять вагонів напівтрупів, і бараки повні до неможливості"5. Ta masowość sprawia, iż baraki stają się miejscem „seryjnego wytwarzania zmarłych"6. Nagromadzenie umierających oraz określanie ich nie inaczej niż trupami, półtrupami czy kawałkami mięsa sprawia, że umieranie traci kulturową otoczkę obrzędu i zmienia się w nagi proces fizjologiczny.

${ }^{1}$ Ю. Лавріненко, Розстріляне відродження. Антологія 1917-1933. Поезія, проза, драма, есей, Київ 2004, s. 406.

${ }^{2}$ A. Nowacki, Myśli pod prąd. Twórczość Mykoty Chwylowego w kontekście ukrainskiej dyskusji literackiej lat 1925-1928, Lublin 2013, s. 7.

3 J. Szapował „Car i niewolnik sprytu”: losy Mykoly Chwylowego w świetle dokumentów NKWD, „Przegląd Archiwalny” 4, 2011, s. 383-410.

${ }^{4}$ Г. Грабович, Тексти і маски, Київ 2005, s. 240.

${ }_{5}^{5}$ М. Хвильовий, Бараки, що за містом, [w:] idem, Вибрані твори, Київ 2011, s. 191.

${ }^{6}$ A. Becker, Eksterminacje. Ciało i obozy, przeł. K. Belaid, T. Stróżyński, [w:] Historia ciata. Różne spojrzenia. Wiek XX, t. 3, red. J. J. Courtine, Gdańsk 2014, s. 302. 
Nazewnictwo jest tu bardzo istotne, gdyż określenie „trup” — jak zauważa Anna Jasik — „wskazuje, że martwe ciało nie jest już kimś, że stało się czymś”7. Francuski tanatolog Louis Vincent Thomas pisze natomiast, iż „trup jest tylko zimną i sztywną rzeczą, należącą do dziedziny fizykochemii”8. „Trup” nie jest zatem człowiekiem, jednostką, indywidualnością.

Albert Nowacki zauważa, iż Chwylowyj bardzo często w swoich nowelach odwoływał się do zmysłów, zwłaszcza zaś do zapachu9. Tak jest również w omawianej noweli, w której motyw „trupiego zapachu”, „trupiego odoru” czy „trupiego smrodu" pojawia się jak refren. W tym krótkim utworze informacje o przykrym zapachu znajdujemy na niemal każdej stronie: „вітер іде широкою вулицею, добігає до бараків і тоді з важким духом трупів несеться до провалля, щоб заритися в сміття" 10 . Odór jest charakterystyczny zarówno dla samych baraków: „Чи не здається вам, що ми вже давно в бараках, де труповий дух?”"1, jak i dla pracujących w nich sanitariuszy: „Мазій дивиться двома ярками. Від нього йде труповий дух" ${ }^{2}$. Najczęściej informacje odwołujące się do zmysłu zapachu i przykrych doznań z nim związanych padają w formie króciutkich zdań lub równoważników, pojawiających się cyklicznie: „Душить труповий дух”" „Пахло трупами”14; „Смерділо трупами” ${ }^{5}$; „Сморід”16.

Poza słowem „trup” na określenie umierających i zmarłych chorych pojawia się w noweli termin „mięso” lub „kawałki mięsa”. Wyrażenie to jest tym bardziej wstrząsające, iż występuje ono w kontekście opisu masowego grobu, w którym dogorywający ludzie są często zakopywani jeszcze przed śmiercią:

Потім рили величезні ями й кидали туди необмиті, чорні, виснажені цурпалки живого м'яса. Не чекали смерті — валили на підводи й везли на цвинтар. Везли на цвинтар наших полонених, що були в Німеччині ${ }^{17}$.

Lub: „Коли розрили свіжу сопку, з могили ще плазував кволий стогін. То цурпалки живого м'яса, що все одно скоро підуть у вічність. Смерділо трупрми"18 (wyr. - M. Z.).

${ }^{7}$ A. Jasik, Tabuizowanie śmierci i realiów z niq związanych w różnych kręgach środowiskowych Opolszczyzny, [w:] Tabu w języku i kulturze, red. A. Dąbrowska, „Język a Kultura” 21, 2009, s. 184-185.

${ }^{8}$ L. V. Thomas, Trup, przeł. K. Kocjan, [w:] Antropologia ciała. Zagadnienia i wybór tekstów, red. M. Szpakowska, Warszawa 2008, s. 306.

${ }^{9}$ A. Nowacki, Problematyka zmysłów i zmysłowości w prozie Mykoty Chwylowego, ,Slavica Wratislaviensia" 161, 2015, s. 157-165.

${ }^{10}$ М. Хвильовий, Бакаки, щуо за містом, [w:] idem, Вибрані твори, Київ 2011, s. 191.

11 Ibidem, s. 193.

12 Ibidem.

13 Ibidem, s. 194.

14 Ibidem, s. 197.

15 Ibidem, s. 200.

${ }^{16}$ Ibidem, s. 203.

17 Ibidem, s. 194.

18 Ibidem, s. 200. 
Przytoczone cytaty wskazują na bardzo istotny element dehumanizacji, przemiany podmiotu w przedmiot, żywego jeszcze, choć już umierającego człowieka w kawałek bezdusznego mięsa, tak dalece pozbawionego atrybutów istoty ludzkiej — czy jakiejkolwiek innej czującej istoty — że możliwe jest zakopanie go żywcem. Ten stosunek do ciała i cielesności jest charakterystyczny dla wszelkich instytucji masowej śmierci, takich jak obozy zagłady, obozy pracy, katownie czy - jak w opowiadaniu Chwylowego - swoiste umieralnie przeznaczone dla więźniów. Jak wspominają autorzy książki Historia ciała, tego rodzaju instytucje nie tyle zezwierzęcały swoich więźniów, ile ich urzeczowiały i całkowicie pozbawiały tożsamości ${ }^{19}$.

W końcowej części noweli dwa razy powtarza się fraza: „Усяка буває смерть, це зрозуміло, і буває смерть, коли від неї смердить трупами"20. Warto przywołać w tym miejscu fragment fenomenalnej pracy Człowiek i śmierć francuskiego tanatologa Philippe’a Ariès, który podkreśla, iż

rytualizacja śmierci jest szczególnym przypadkiem ogólnej strategii człowieka w walce z naturą, strategii, na którą składają się zakazy i zezwolenia. Oto dlaczego nie pozostawiono śmierci samej sobie [...], lecz przeciwnie, uwięziono ją w ceremoniach, zmieniono w widowisko ${ }^{21}$.

Pojawia się więc pytanie: „Kim są ludzie, którzy zatracili ów podstawowy, niemal biologiczny instynkt bojaźni przed aktem śmierci i dążenia do »ubrania« go w kostium kultury?". Jaka nadrzędna, mająca zapewne moc nieogarnionego żywiołu siła polityczna, społeczna, historyczna wytworzyła tę postawę?

Mykoła Chwylowyj przedstawiając w swoich nowelach konstytuowanie się w walkach i rewolucyjnych zmaganiach nowego ładu społecznego, opisuje zarazem pojawienie się ,nowego człowieka”. Nie jest to jednak - mimo zdecydowanie prokomunistycznej orientacji autora — obraz optymistyczny. W noweli Бараки... Chwylowyj - zgodnie ze słowami Ewgenija Lepiohina - nie tyle daje dowód procesowi demoralizacji i atrofii człowieczeństwa, ile konstatuje apogeum tego procesu w osobie sanitariusza Mazija ${ }^{22}$. Jest to sadystyczny człowiek-automat, który aby wesprzeć bolszewików w walce w Niemcami, postanawia zakopać żywcem przedstawiciela okupacyjnej władzy. Ten bestialski akt określa jednoznacznie stosunek do człowieka w sytuacji, gdy ideologia i rozmaicie rozumiana „wyższa konieczność” dzielą ludzi na kategorie godnych i niegodnych życia i ludzkiego traktowania. Kategoria „wroga” implikuje dehumanizację, a masowość śmierci zmienia ów akt w bezduszną statystykę gromadzącą kolejne martwe ciała. Бараки, що за містом to utwór przedstawiający śmierć w sposób wstrząsający. Słowo „trup” stanowi w nim podstawową jednostkę leksykalną,

19 A. Becker, Eksterminacje. Ciało i obozy..., s. 308.

${ }^{20}$ М. Хвильовий, Бараки, щчо за містом..., s. 203-204.

${ }^{21}$ P. Aries, Człowiek $i$ śmierć, przeł. E. Bąkowska, Warszawa 2011, s. 601.

22 С. Лепьохін, Культурно-історичний контекст і свідомість інваліда: деструктивні форми рецепції світу в новелі Бараки, щзо за містом Миколи Хвильового, „Науковий Вісник Ужгородського Університету" 2016, nr 2, s. 167. 
powtarzającą się na niemal każdej stronie. Ograniczona do baraków, grobów i kilku ulic przestrzeń literacka jest obszarem makabrycznej „fabryki produkującej trupy”. Szczególnie poruszający jest cytowany już fragment, w którym pada stwierdzenie, że owe zakopane żywcem kawałki ludzkiego mięsa i tak niedługo odejdą do wieczności („цурпалки живого м’яса, що все одно скоро підуть у вічність”). Użycie pojęcia wieczności i całego religijno-duchowego kompleksu związanych z nim symboli brzmi groteskowo i potwornie w sąsiedztwie określenia ,żywe mięso".

Równie wstrząsający, choć z innych przyczyn, jest obraz śmierci w najbardziej chyba znanej noweli Chwylowego — Я (Романтика). Napisany w 1924 roku utwór jest fabularyzowanym świadectwem czystek lat dwudziestych, przedstawionych $\mathrm{w}$ formie onirycznych wizji głównego bohatera przeplatanych kadrami kroniki pracy funkcjonariuszy Czeka. Jak zauważa Albert Nowacki, czytelnikowi dość trudno oddzielić sny i urojenia bohatera od rzeczywistych wydarzeń ${ }^{23}$. Obie płaszczyzny przeplatają się, tworząc nastrój chorobliwej egzaltacji i neurotycznej walki wewnętrznej. Jednak niezależnie od tego, czy opisane wydarzenia mają miejsce w śnie czy w życiu bohatera, dominującym motywem noweli jest śmierć zadawana niezliczonym anonimowym „wrogom komuny”. Przesłuchania, podpisywanie wyroków i masowe rozstrzeliwania składają się na codzienność bohatera. Działalność funkcjonariuszy Czeka jest w noweli ukazana jako monotonna męcząca praca: „будуть сотні розстрілів, і я остаточно збиваюся 3 нiг!"24. Owa rutynowość rozstrzeliwań zdaje się najtrudniejsza do zniesienia dla czytelnika śledzącego wydarzenia z perspektywy kata (rozdartego co prawda dramatycznym konfliktem wewnętrznym, lecz ostatecznie godzącego się na swoją rolę). Charakterystyczna w tym opowiadaniu jest również anonimowość i dehumanizacja ofiar. Zewnętrzne wyznaczniki tożsamości, takie jak imię, nazwisko, zawód itp., tracą znaczenie - skazany na śmierć człowiek zalicza się do zbiorczej kategorii „wrogów”. Owa anonimowość oraz skala, na jaką zadawana jest śmierć, zmieniają dramat jednostki w suchą statystykę. Dowodem tego może być następująca scena, w której do bohatera czekisty wprowadzane są kolejne osoby skazywane na śmierć:

женщина в траурі й мужчина в пенсне. [...] Я:

- Ваша фамілія?

- Зeт!

- Ваша фамілія?

- Ігрек! [...]

- Де вас забрали?

- Там-то!

- За що вас забрали?

- За те-то!

23 A. Nowacki, ,Btękitny sen o rewolucji”. Poetyka oniryczna w prozie Mykoty Chwylowego, „Slavica Wratislaviensa” 155, 2012, s. 211-220.

${ }^{24}$ М. Хвильовий, Я (романтика), [w:] idem, Вибрані твори, Київ 2011, s. 338. 


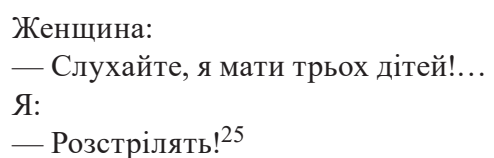

Mordowanie staje się nie tylko pracą, lecz także świętym obowiązkiem, a fanatyzm czekistów porównywany jest do ekstazy świętej wojny: „Я входив у роль. Туман стояв перед очима, і я був у тім стані, який можна кваліфікувати як надзвичайний екстаз. Я гадаю, що в такім стані фанатики йшли на священну війну” "26. Ideą, ową „wyższą koniecznością”, w imię której mordowanie staje się powinnością, jest mglista wizja „błękitnej komuny za górami” — jakiejś fantastycznej, niezrealizowanej iluzji lepszego świata. Czas, w którym rozgrywają się wydarzenia, stanowi rodzaj okresu przejściowego między zniszczonym już starym porządkiem a wyłanianiem się nowego ładu. W tym miejscu można powołać się na ustalenia Rogera Caillois, który w tekście Wojna i sacrum porównuje strukturę czasu wojny i czasu święta. Wychodząc od fenomenologicznej koncepcji sacrum, Caillois określa to ostatnie jako rzeczywistość dwubiegunową, która obejmuje zarówno aspekt boski, powiązany z czystością, świętością, jak i demoniczny, utożsamiany z sferą rzeczy i sytuacji kalających czy przerażających ${ }^{27}$. Jeszcze przed Caillois o grozie sacrum pisał Rudolf Otto, wspominając, iż w obliczu świętości człowiek doznaje poczucia grozy i zależności ${ }^{28}$. Podobną grozę i poczucie bezsilności wywołuje doświadczenie wojny oraz wszelkie sytuacje gwałtownych przewrotów społecznych i politycznych połączonych z niekontrolowanym, zakrojonym na szeroką skalę zadawaniem przemocy i śmierci. Caillois stwierdza, że takie okresy w życiu społecznym i politycznym stanowią — podobnie jak okres karnawału/święta - czasowe przekroczenie codziennej kondycji. Zarówno wojna, jak i święto stanowią okres nadużyć i gwałcenia najświętszych praw, gdy to, co było zbrodnią, staje się regułą. Fundamentalna różnica polega oczywiście na tym, że o ile święto opiera się na zachowaniach symbolicznych, o tyle zakaz odbierania życia zmienia się podczas wojny czy podczas trwania politycznego terroru w realny nakaz zabijania, a bezustanna obecność śmierci odwraca perspektywę postrzegania siebie i świata. Francuski filozof pisze, iż bezustanna „obecność śmierci przyprawia o drżenie i różnym uczynkom nadaje wartość najwyższą" 29 .

Ustalenia te znajdują potwierdzenie w noweli Mykoły Chwylowego, której bohater owładnięty ideą , „cichych jezior komuny za górami” gotowy jest na każdą zbrodnię w imię osiągnięcia i wprowadzenia w życie owej ulotnej wizji. Co więcej, zgoda na masowe rozstrzeliwania staje się czynem uświęconym przez swój

25 Ibidem, s. 339-341.

${ }^{26}$ М. Хвильовий, Я (романтика), s. 341.

27 R. Caillois, Człowiek i sacrum, przeł. A. Tatarkiewicz, E. Burska, Warszawa 1995, s. 37-38.

${ }^{28}$ R. Otto, Świętość. Elementy irracjonalne w pojęciu bóstwa i ich stosunek do elementów racjonalnych, przeł. B. Kupis, Warszawa 1999, s. 25.

${ }^{29}$ R. Caillois, Człowiek i sacrum..., s. 284. 
wyimaginowany cel, rodzajem wypaczonego heroizmu. Dowodzi tego wprowadzony przez autora dramatyczny motyw konieczności skazania na śmierć własnej matki. Stojąc wobec tragicznego wyboru, bohater wypowiada słowa dowodzące, iż znajduje się on w stanie fanatycznego amoku. Naturalne ludzkie odruchy, takie jak rozpacz i chęć ratowania matki, definiuje jako „zdradę ideałów rewolucji”. Ostatecznie jego człowieczeństwo przegrywa z rewolucyjnym opętaniem, a narrator stwierdza:

Мислі різали мій мозок. Що я мушу робити? Невже я, солдат революції, схиблю в цей відповідальний момент. Невже я покину чати й ганебно зраджу комуну? Я здавив щелепи, похмуро подивився на матір і сказав різко - Всіх у підвал. [...] 3 цією сволоччю! — я махнув рукою в бік, де стояла моя мати ${ }^{30}$.

W ostatniej scenie noweli, zbudowanej z niezwykłym wyczuciem dramatyzmu, autor przedstawia długą, milczącą procesję, którą bohater wraz z konwojem czekistów prowadzi na miejsce rozstrzelania za miastem. W tłumie idzie matka bohatera, którą syn-morderca odprowadza w ostatniej ziemskiej drodze. Ten wynaturzony obraz procesji pogrzebowej wywiera na czytelniku tym bardziej wstrząsające wrażenie, iż rytuał wspólnego odprowadzania bliskich zmarłych na miejsce pochówku to jeden z ważniejszych i bardziej podniosłych obrzędów życia rodzinnego. Chwylowyj kreuje tu obraz świata na opak, jakiegoś antyludzkiego uniwersum, w którym nastąpiło potworne odwrócenie porządku zarówno na poziomie materialnym (ci, których należy pochować, idą na cmentarz na własnych nogach, „pogrzebowy konwój” składa się z tłumu skazańców, towarzyszący im w ostatniej drodze są w istocie katami, a sam cmentarz to wykopany za miastem dół), jak i duchowym (syn zabija matkę, łamiąc tym tradycyjne nakazy ludzkie i boskie). Ten nowy świat to obraz świata na opak czy świata nie-ludzkiego.

Śmierć w obu opisanych nowelach ma wymiar masowy, dehumanizujący i uprzedmiatawiający. Ofiarami są jednak nie tylko skazani na śmierć, lecz także główni bohaterowie, gdyż to właśnie ich — w wymiarze indywidualnym — dotyczy proces powolnego, wewnętrznego obumierania. Zatracając człowieczeństwo, stają się oni żywymi trupami. W noweli Бараки, щзо за містом mamy do czynienia $\mathrm{z}$ bohaterem, który w czasie fabularnym nie przechodzi ewolucji. Poznajemy go już jako jednostkę zdehumanizowaną, człowieka-automat. Nie dowiadujemy się absolutnie niczego o jego wewnętrznym świecie, a informacje o nim pochodzą jedynie z zewnętrznej obserwacji jego czynów oraz opinii pozostałych postaci. Inaczej przedstawia się to $\mathrm{w}$ drugim utworze, w którym wewnętrzna walka narratora-bohatera stanowi kanwę konstrukcyjną fabuły. Czytelnik widzi rzeczywistość przefiltrowaną przez znajdującą się na skraju histerii świadomość funkcjonariusza Czeka, który kilkakrotnie powtarza wiele mówiące zdanie: ,jestem czekistą, ale też człowiekiem" "31. Bohater odwołuje się również do kategorii sumienia, mówiąc, iż na jego sumieniu ciążą miliony istnień ludzkich: „шість

\footnotetext{
${ }^{30}$ М. Хвильовий, Я (романтика), s. 343.

31 Ibidem, s. 332.
} 
сотень, шість тисяч, шість мільйонів - тьма на моій совісті!!!”32. Degradacja, a de facto śmierć, sumienia następuje stopniowo, po symbolicznej „walce o duszę" bohatera, w której zmagają się siły dobra/miłości/światła (uosobione w postaci Matki-Maryi) i zła/ciemności (towarzysze-funkcjonariusze, tak zwany czarny trybunał komuny w postaciach doktora Tahabata i Degenerata). Ten ostatni — sadysta o wymownym pseudonimie — został przez bohatera jednoznacznie określony „stróżem jego duszy”33, niedopuszczającym do niej niczego poza ślepym oddaniem komunistycznej idei.

$\mathrm{Na}$ zakończenie chciałabym zwrócić uwagę na ciekawą paralelę literacką między nowelą $J a$ (Romantyka) a napisaną mniej więcej w tym samym okresie krótką powieścią rosyjskiego autora Władimira Zazubrina Drzazga. Opowieść o niej i o niej. (Щепка, 1923) Zarówno tematyka utworów, jak i wykorzystane przez autorów środki stylistyczne, dzieje samych tekstów, a także los autorów - zmarłych tragicznie w latach trzydziestych (Zazubrin został rozstrzelany w 1938 roku) - wykazują wiele podobieństw ${ }^{34}$. Oba utwory są literackimi relacjami z „fabryki śmierci”, opowiedzianymi z perspektywy oprawców, funkcjonariuszy Czeka. Obie stanowią studium fanatycznego zaślepienia i przedstawiają zadawanie śmierci w kategoriach ,powinności” i „,wyższej konieczności”. W obu też pojawia się wątek zabójstwa rodziców, symbolizującego wewnętrzną śmierć bohatera oraz wyrzeczenie się wartości konstytuujących kulturę. W powieści Zazubrina bohater skazuje na śmierć ojca, który przed egzekucją wypowiada do syna znamienne słowa: „Ты думаешь на миллионах замученных, расстрелянных, уничтоженных воздвигнуть здание человеческого счастья..." 35 . Słowa te, stanowiące nawiązanie do powieści Bracia Karamazow (Братья Карамазовы, 1880), zostają zagłuszone szaleństwem, jakim owładnięty jest główny bohater. Również w tym utworze czytelnik zagląda w obszar ,świata niemożliwego" za pośrednictwem chorej, zdegenerowanej szaleństwem psychiki głównego bohatera, a proces jego powolnej duchowej i mentalnej śmierci został zobrazowany za pomocą zawężenia perspektywy wewnętrznej i zewnętrznej wolności. W dodatku zarówno Mykoła Chwylowyj, jak i Władimir Zazubrin zostali na dziesięciolecia wymazani ze świadomości czytelników, nie istnieli na mapie ukraińskiej i rosyjskiej literatury. Do literackiego życia powrócili dopiero pod koniec lat osiemdziesiątych wraz z plejadą twórców zamordowanych w sensie fizycznym i literackim.

32 Ibidem, s. 336.

33 Ibidem, s. 345.

${ }^{34}$ Porównanie tych utworów przeprowadziłam w krótkim tekście Świadkowie $w$ fabryce śmierci. Drzazga. Opowieść o niej i o niej Władimira Zazubrina i Ja (Romantyczność) Mykoły Chwylowego, [w:] Wschód oczami młodych, red. K. Bortnowska, A. Chyckowska, Warszawa 2010, s. $123-131$.

35 В. Зазубрин, Щепка, Litmir.mu, https://www.litmir.me/br/?b=45680\&p=8 [dostęp: 3.07.2018]. 


\section{Bibliografia}

Aries P., Człowiek i śmierć, przeł. E. Bąkowska, Warszawa 2011.

Becker A., Eksterminacje. Ciało i obozy, przeł. K. Belaid, T. Stróżyński, [w:] Historia ciała. Różne spojrzenia. Wiek XX, t. 3, red. J. J. Courtine, Gdańsk 2014.

Caillois R., Człowiek i sacrum, przeł. A. Tatarkiewicz, E. Burska, Warszawa 1995.

Caillois R., Wojna i sacrum, przel. A. Tatarkiewicz, [w:] Antropologia widowisk, red. L. Kolankiewicz, Warszawa 2008.

Grabovych G., Teksty i masky, Kyi'v 2005.

Hvyl'ovyj M., Baraky, shho za mistom, [w:] idem, Vybrani tvory, Kyi'v 2011.

Hvyl'ovyj M., Ja (romantyka), [w:] idem, Vybrani tvory, Kyi'v 2011.

Jasik A., Tabuizowanie śmierci i realiów z niq zwiąanych $w$ różnych kręgach środowiskowych Opolszczyzny, [w:] Tabu w języku i kulturze, red. A. Dąbrowska, „Język a Kultura” 21, 2009.

Lavrinenko J., Rozstriljane vidrodzhennja. Antologija 1917-1933. Poezija, proza, drama, esej, Kyi’v 2004.

Lep'ohin J., Kul'turno-istorychnyj kontekst $i$ svidomist' invalida: destruktyvni formy recepcii' svitu v noveli Baraky, shho za mistom Mykoly Hvyl'ovogo, „Naukovyj Visnyk Uzhgorods'kogo Universytetu" 2016, nr 2.

Nowacki A., ,Błękitny sen o rewolucji”. Poetyka oniryczna w prozie Mykoły Chwylowego, „Slavica Wratislaviensa" 155, 2012.

Nowacki A., Myśli pod prąd. Twórczość Mykoły Chwylowego w kontekście ukraińskiej dyskusji literackiej lat 1925-1928, Lublin 2013.

Nowacki A., Problematyka zmystów i zmystowości w prozie Mykoły Chwylowego, „Slavica Wratislaviensia" 161, 2015.

Otto R., Świętość. Elementy irracjonalne w pojęciu bóstwa i ich stosunek do elementów racjonalnych, przeł. B. Kupis, Warszawa 1999.

Szapował J., „Car i niewolnik sprytu”: losy Mykoły Chwylowego w świetle dokumentów NKWD, „Przegląd Archiwalny” 4, 2011.

Thomas L. V., Trup, przeł. K. Kocjan, [w:] Antropologia ciała. Zagadnienia i wybór tekstów, red. M. Szpakowska, Warszawa 2008.

Zazubrin V., Shepka, Litmir.me, https://www.litmir.me/br/?b=45680\&p=8.

\section{The image of mass death in Mykola Khvylovy's novellas Barracks Outside the Town and I (Romantica)}

\section{Summary}

The author of this article analyzes two novellas by Mykola Khvylovy as examples of the literary representation of the subject of mass death. Khvylovy, who belonged to The Executed Renaissance generation, committed suicide at the age of 33 in 1933 to protest against Stalinism and the new reality. Death in the name of "superior necessity" is also a motif that appears in some of his works, especially in the novella I (Romantica), which is the main subject of this article. The shocking image of mass death also appears in Barracks Outside the Town.

Keywords: mass death, The Executed Renaissance, Mykola Khvylovy, body, corpse 


\section{Зображення масової смерті в новелах Миколи Хвильового Бараки, что за містом і Я (Романтика)}

Резюме

Для зображення теми масової смерті в літературі авторка обрала дві новелі українського письменника, представника Розстріляного Відродження Миколи Хвильового. Його самогубство у 33 році, яке було протестом проти сталінізму і виразом відчаю перед обличчям нової реальності, само по собі вписується в проблематику масової смерті, що зумовлена політичним контекстом. Масове умертвлення, яке відбувається в ім'я „вищої необхідності" є темою, яка з'являється в деяких творах Хвильового, особливо в новелі Я (Романтика), яка буде основним об'єктом мого аналізу. Шокуючу картину масової смерті, ми також знаходимо в новелі Бараки, что за містом.

Ключові слова: масова смерть, Розстріляне Відродження, Микола Хвильовий, тіло, труп

Slavica Wratislaviensia 168, 2019

(C) for this edition by CNS 